\title{
AKTIVITAS ANTIINFLAMASI EKSTRAK AIR TEPUNG PELEPAH AREN (Arenga pinnata)
}

\author{
Fita M. Onggeteua ${ }^{1}$, Meiske S. Sangi ${ }^{1}$, Audy D. Wuntu ${ }^{1}$ \\ ${ }^{1}$ Program Studi Kimia, Fakultas Matematika dan Ilmu Pengetahuan Alam \\ Universitas Sam Ratulangi Manado
}

\begin{abstract}
ABSTRAK
Penelitian ini bertujuan untuk menguji aktivitas antiinflamasi dari beberapa dosis ekstrak fraksi air tepung pelepah aren terhadap tikus putih galur wistar (Rattus norvegicus L.) yang diinduksi karagenan berdasarkan nilai persen inhibisi radang. Metode yang digunakan untuk pengujian antiinflamasi adalah dengan induksi karagenin $1 \%$ sebanyak $0,5 \mathrm{~mL}$ pada telapak kaki belakang hewan uji 1 jam sebelum perlakuan terhadap tikus diberikan secara peroral. Hasil penelitian menunjukkan dosis yang paling bagus dalam menghambat inflamasi yaitu dosis $30 \%$ dimana mempunyai nilai persen inhibisi udem lebih tinggi dari kontrol positif (Na-diklofenak). Pada uji KolmogorovSmirnov, data persen inhibisi udem pada semua kelompok uji dari jam 1 sampai ke 6 terdistribusi normal $(\rho \geq 0.05)$. Pada uji Homogenitas Levene, data persen inhibisi udem pada semua kelompok uji dari jam 1 sampai ke 6 terdistribusi homogen ( $\rho \geq 0.05)$. Pada uji One-way ANOVA, nilai signifikan dari persentase inhibisi udem jam ke-1 sampai jam ke-6 yaitu berbeda secara bermakna $(\rho \leq 0,05)$. Pada uji BNT (LSD), dosis $30 \%$ memiliki nilai signifikan ( $\rho \leq 0.05$ ). Sedangkan dosis $20 \%$ dan $25 \%$ tidak memiliki nilai signifikan. Maka dapat disimpulkan bahwa data persen inhibisi udem telapak kaki tikus dengan dosis $30 \%$ berbeda secara bermakna.
\end{abstract}

Kata kunci : pelepah aren, Tikus, karagenin, Antiinflamasi

\section{ABSTRACT}

The present study aimed to discuss the anti-inflammatory activity of several doses of extract of water fraction of palm sugar flour on rats of Wistar (Rattus norvegicus L.) strain induced carrageenan based on percent inhibitory inflammation values. The method used to test anti-inflammatory is by induction of caragenin $1 \%$ by $0.5 \mathrm{~mL}$ on the soles of the test animal's feet 1 hour before evaluation of rats given orally. The results showed that the best dose against inflammation was the $30 \%$ dose which had a higher percent inhibition value than positive control (Nadiclofenac). In the Kolmogorov-Smirnov test, percent data inhibited in all test groups from 1 to 6 hours were normally distributed $(\rho \geq 0.05)$. In the Levene Homogeneity test, percent inhibition data in all test groups from 1 to 6 hours were homogeneously distributed $(\rho \geq 0.05)$. In the One-way ANOVA test, the significant value of the percentage of inhibition of the 1 st to 6 th hour edema was different from the contribution $(\rho \leq 0.05)$. In the LSD test (LSD), a dose of $30 \%$ has a significant value ( $\rho \leq 0.05)$. While the doses of $20 \%$ and $25 \%$ have no significant value. Then it can be concluded that the percent data inhibits rat foot edema at a dose of $30 \%$ significantly different.

Keywords : sugar palm midrib, Rat, Carrageenan, Anti-inflammatory

\section{PENDAHULUAN}

Indonesia kaya akan keanekaragaman hayati yang dapat dimanfaatkan dalam semua aspek kehidupan manusia. Obat tradisional adalah salah satu bentuk nyata pemanfaatan sumber daya hayati tersebut. Salah satu tanaman yang merupakan obat tradisional adalah tanaman aren.

Berdasarkan pengalaman empiris masyarakat, khususnya masyarakat yang ada di desa Pakuure Minahasa Selatan, tepung pelepah aren digunakan sebagai obat gatal dengan cara mengoleskan tepung pelepah aren ke bagian yang gatal dan masyarakat Sunda menggunakan abu pelepah daun aren yang telah dibakar sebagai bahan kosmetik tradisional untuk menghilangkan jerawat. Zainudin et al., (2015), melaporkan bahwa ekstrak akar aren mengandung senyawa metabolit sekunder, yaitu flavonoid, alkaloid, steroid/triterpenoid, tanin, saponin, terpenoid, antrakuinon. Sangi et al., (2012), melaporkan bahwa tepung pelepah daun aren mengandung senyawa fitokimia alkaloid, tanin, triterpenoid.

Inflamasi atau radang merupakan suatu respon protektif tubuh terhadap cedera. Respon inflamasi ditandai dengan adanya warna merah karena adanya aliran darah yang berlebihan pada daerah cedera, panas yang merupakan respon inflamasi pada permukaan tubuh dan rasa nyeri karena adanya penekanan jaringan akibat udem. Udem adalah akumulasi cairan yang berlebihan dibawah kulit dalam ruang-ruang didalam jaringan-jaringan tubuh. Secara prinsip 
pembengkakan terjadi karena adanya water retension (penimbunan air) di dalam tubuh dan dengan adanya pengaruh gavitasi maka wilayah betis dan kaki yang paling seringan mengalami pembengkakan (udem).

Metode yang biasa digunakan pada penelitian antiinflamasi adalah metode Rat hind paw udem, yaitu pembengkakan radang buatan pada telapak kaki hewan uji yang diinduksi karagenan (Necas, 2013). Penelitian ini bertujuan untuk menguji aktivitas antiinflamasi dari beberapa dosis ekstrak fraksi air tepung pelepah aren terhadap tikus putih galur wistar (Rattus norvegicus L.) yang diinduksi karagenan berdasarkan nilai persen inhibisi radang.

\section{BAHAN DAN METODE}

\section{Alat dan bahan}

Alat-alat yang akan digunakan adalah, seperangkat alat destilasi, oven (memmert), toples, cawan petri, batang pengaduk, corong pisah, corong, pipet tetes, gelas ukur, desikator, neraca analitik, rotary evaporator, mortar, jarum sonde, dispo, kandang tikus, tempat minum dan makan tikus, spidol, stopwatch.

Bahan-bahan yang digunakan adalah tepung pelepah aren, diambil dari Tobelo, Halmahera Utara. Tikus Putih Jantan Galur Wistar (Rattus norvegicus L.) yang diambil dari desa Kamanga, Kabupaten Minahasa Tenggara, aluminum foil, kertas saring (whatman 24), tissue, etanol (hasil redestilasi cap tikus), etil asetat (pa), aquadest, makanan tikus (butiran susu dan tepung jagung), $\mathrm{CMC} 1 \%$, Natrium diklofenak, Karagenin 1\%, larutan infus $\mathrm{NaCl}$.

\section{Ekstraksi dan fraksinasi}

Ekstraksi dan fraksinasi sampel mengikuti Prasetyo et al., (2016) dengan sedikit modifikasi. Sebanyak 1.500 gram tepung pelepah aren dimaserasi menggunakan etanol (hasil redestilasi cap tikus $80 \%$ ) sebanyak 12.5 L selama $2 \times 24$ jam, disaring kemudian diuapkan menggunakan rotary evaporator pada suhu $40^{\circ} \mathrm{C}$ selama 2 hari. Ekstrak etanol yang diperoleh kemudian disimpan lalu dilanjutkan pada tahap partisi. Sebanyak 25 gr ekstrak etanol awal dilarutkan dalam $50 \mathrm{~mL}$ aquades. Larutan selanjutnya dipartisi dengan menambahkan $50 \mathrm{~mL}$ pelarut etil asetat, dikocok dalam corong pisah dan didiamkan selama 2 jam hingga terdapat dua lapisan (air pada lapisan bawah dan etil asetat pada lapisan atas). Dilakukan beberapa kali hingga lapisan aquades terlihat bening.Hasil fraksinasi diuapkan menggunakan rotary evaporator pada suhu $100^{\circ} \mathrm{C}$ dan dikeringkan dalam oven dengan suhu $50^{\circ} \mathrm{C}$ selama 2 hari sehingga didapati fraksi air.

\section{Pengujian efek antiinflamasi}

Uji efek antiinflamasi mengikuti Sutrisna, (2010). Hewan uji yang digunakan untuk pengujian sebanyak 15 ekor tikus putih jantan galur wistar dibagi dalam 5 kelompok perlakuan yang tiap kelompok terdiri dari 3 ekor tikus. Semua tikus diaklimatisasi terhadap lingkungan minimal 1 minggu. Sebelum dilakukan pengujian hewan uji dipuasakan selama 18 jam (minum tetap diberikan). Perlakuan pada tikus putih jantan dilakukan secara peroral dengan menggunakan jarum sonde.

\section{Analisis data}

Data yang diperoleh dari hasil

penelitian dianalisis menggunakan IBM

SPSS Statistics 21.

\section{HASIL DAN PEMBAHASAN}

\section{Ekstraksi dan fraksinasi}

Pelarut yang digunakan dalam ekstraksi adalah etanol. Etanol merupakan pelarut polar dan merupakan pelarut yang baik untuk ekstraksi karena dapat mengekstrak senyawa-senyawa polar dan non polar. Hal ini dikarenakan adanya gugus hidroksil $(-\mathrm{OH})$ yang bersifat polar dan gugus alkil $\left(-\mathrm{CH}_{2}-\mathrm{CH}_{3}\right)$ yang bersifat non polar (Harborne, 1987).

Partisi pada tepung pelepah aren bertujuan untuk memisahkan senyawa berdasarkan kelarutannya terhadap pelarut dengan tingkat kepolaran yang berbeda-beda seperti prinsip like dissolve like. Rendemen hasil partisi fraksi air tepung pelepah aren sebesar $40 \%$.

\section{Hasil Pengujian Antiinflamasi}

Inflamasi merupakan suatu mekanisme pertahanan yang dilakukan oleh tubuh untuk melawan agen asing yang masuk ke tubuh, tidak hanya itu inflamasi juga bisa disebabkan oleh cedera jaringan oleh karena trauma, bahan kimia, panas, atau fenomena lainnya. (Guyton dan Hall, 1997). Hewan uji yang digunakan adalah tikus putih jantan galur wistar (Rattus Norvegicus L.) karena kondisi biologisnya lebih stabil dibandingkan dengan tikus betina yang kondisi biologisnya dipengaruhi masa siklusnya (estrus).dengan berat badan berkisar antara 80- 
125 gam dengan usia 2-3 bulan. Hal tersebut juga dapat dilihat pada gambar 1 .

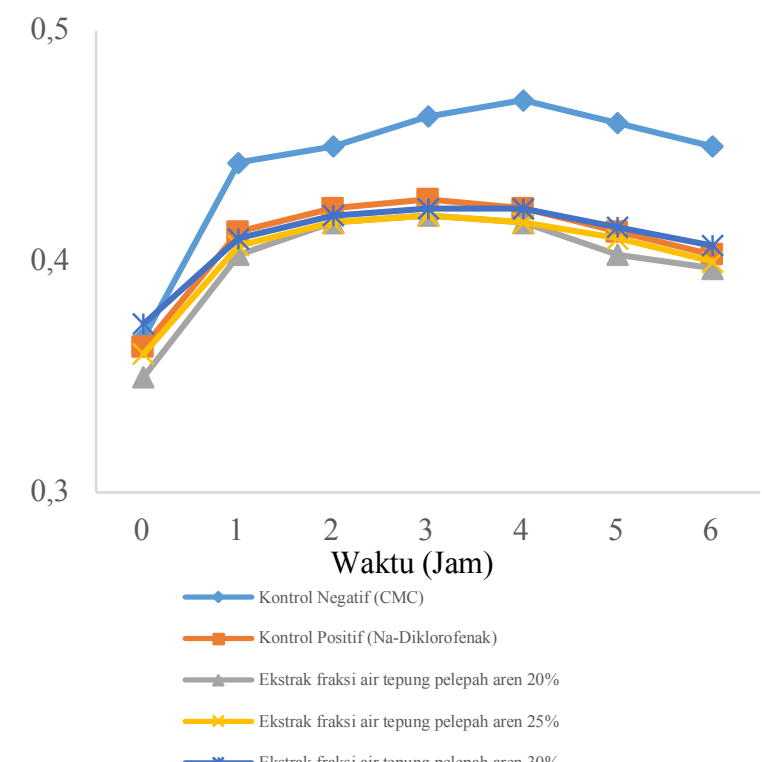

Gambar 1. Gafik hubungan rata-rata volume udem terhadap waktu

Kenaikan volume udem kaki tikus setelah diinduksi karagenan terjadi di setiap pengamatan pada kelompok kontrol negatif (CMC), kontrol positif (Na-diklofenak), ekstrak fraksi air tepung pelepah aren $20 \%$, ekstrak fraksi air tepung pelepah aren $25 \%$ dan ekstrak fraksi air tepung pelepah aren $30 \%$.

Pada kelompok perlakuan ekstrak 20\% terdapat penurunan volume udem kaki tikus di jam ke-4, untuk ekstrak 25\% terdapat penurunan volume udem kaki tikus di jam ke-4 sedangkan ekstrak $30 \%$ terdapat penurunan volume udem kaki tikus di jam ke-5.

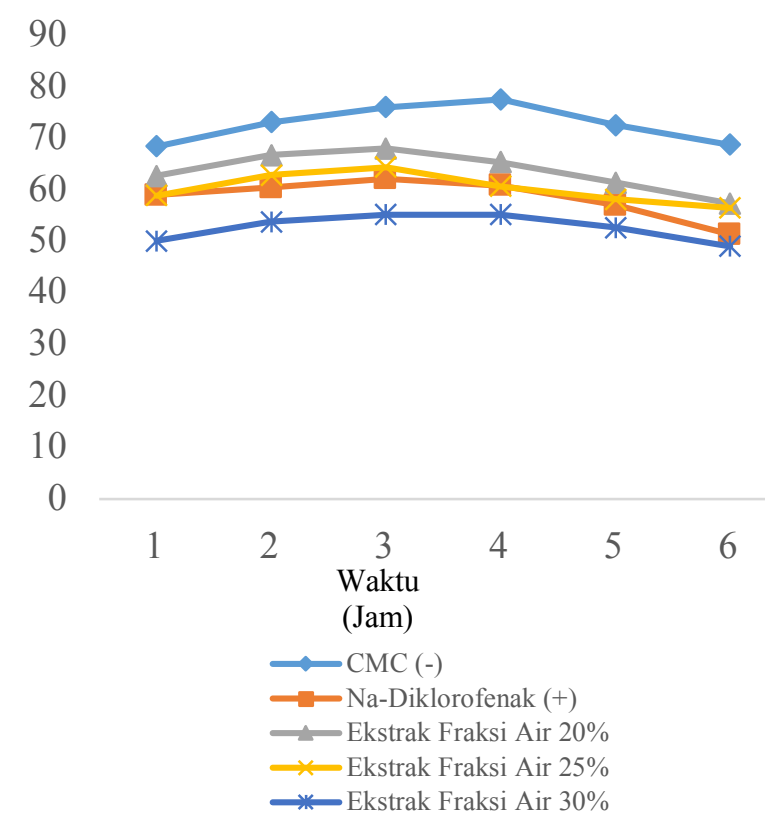

Gambar 2. Gafik Hubungan persen rata-rata udem terhadap waktu

Gambar 2 merupakan perhitungan persen rata-rata udem (kenaikan volume kaki) dilakukan dengan membandingkan volume dasar sebelum menyuntikan karagenan, perhitungan persen udem dilakukan untuk tiap 1 jam. Rata-rata persen volume udem paling besar yaitu ekstrak fraksi air tepung pelepah aren $20 \%$, ekstrak fraksi air tepung pelepah aren $25 \%$ dan ekstrak fraksi air tepung pelepah aren $30 \%$.

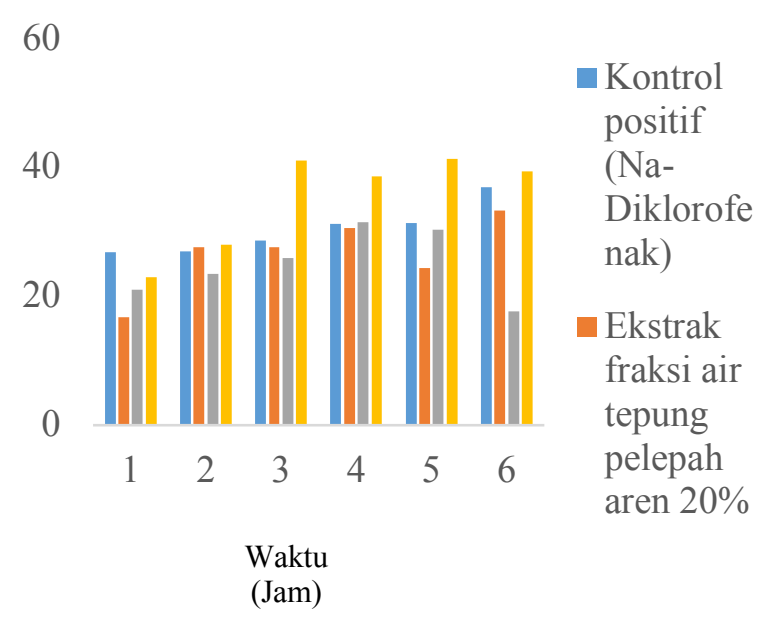

Gambar 3. Gafik hubungan persen rata-rata inhibisi udem terhadap waktu

Gambar 3 menunjukkan kenaikan persen inhibisi udem terus meningkat mulai dari jam ke3 sampai jam ke-6. Pada kelompok uji ekstrak fraksi air tepung pelepah aren $20 \%$ dan ekstrak fraksi air tepung pelepah aren $25 \%$ mengalami kenaikan mulai dari jam ke-3 sampai jam ke-6. Sedangkan pada kelompok uji ekstrak fraksi air tepung pelepah aren $30 \%$ mengalami penurunan di jam ke-4 kemudian mengalami kenaikan pada jam ke-5 sampai jam ke-6.

Berdasarkan hasil uji dimungkinkan bahwa ekstrak fraksi air tepung pelepah aren 30\% mempunyai efek antiinfamasi. Hal tersebut disebabkan karena dosis yang lebih tinggi justru menyebabkan pelepasan histamin (mediator kimia) secara langsung dari mast cell sehingga mengakibatkan pembuluh darah menjadi lebih permeable terhadap cairan plasma dan menimbulkan proses peradangan ( Fitriyani et al., 2011). Adanya efek antiinflamasi diduga karena aktivitas metabolit sekunder yang terdapat dalam ekstrak fraksi air tepung pelepah aren yaitu flavonoid, mekanisme kerja flavonoid sebagai antiinflamasi dapat melalui beberapa jalur dengan penghambatan aktivitas siklooksigenase (COX) 
dan lipooksigenase, penghambatan akumulasi leukosit, penghambatan deganulasi neutrofil, penghambatan histamin (Nijveltd, 2001). Selain itu, mekanisme flavonoid dalam menghambat terjadinya radang melalui dua cara yaitu menghambat asam arakidonat dan sekresi enzim lisosom dan endothelial sehingga proliferasi dan eksudasi dari proses radang. Terhambatnya pelepasan asam arakidonat dari sel inflamasi akan menyebabkan kurang tersediannya subtract arakidonat bagi jalur siklooksigenase dan jalur lipooksigenase (Robinson, 1995). Selain flavonoid senyawa bioaktif lain yang berpotensi sebagai antiinflamasi adalah saponin. Mekanisme antiinflamasi saponin dengan menghambat pembentukan eksudat dan menghambat permeabilitas vaskular (Hernani dan Winarti, 2011).

Signifikansi merupakan besarnya probabilitas atau peluang untuk memperoleh kesalahan dalam mengambil keputusan (Walpole, 1995). Berdasarkan hasil uji normalitas dengan metode Kolmogorov-Smirnov diketahui nilai signifikan dari persentase inhibisi udem jam ke-1 sampai dengan jam ke-6 yaitu ( $\rho \geq 0.05)$. Maka dapat disimpulkan bahwa data persen inhibisi udem telapak kaki tikus terdistribusi normal. Hasil uji homogenitas dengan metode Levene diketahui nilai signifikan dari persentase inhibisi udem yaitu $(\rho \geq 0.05)$. Maka dapat disimpulkan bahwa data persen inhibisi udem telapak kaki tikus terdistribusi homogen. Hasil uji One-Way ANOVA diketahui nilai signifikan dari persentase inhibisi udem jam ke-1 sampai jam ke6 yaitu $(\rho \leq 0,05)$. Maka dapat disimpulkan bahwa data persen inhibisi udem telapak kaki tikus berbeda secara bermakna. Dan hasil uji BNT dengan metode LSD diketahui dosis $30 \%$ memiliki nilai signifikan $(\rho \leq 0.05)$. Sedangkan dosis $20 \%$ dan $25 \%$ tidak memiliki nilai signifikan. Maka dapat disimpulkan bahwa data persen inhibisi udem telapak kaki tikus dengan dosis $30 \%$ berbeda secara bermakna.

Tabel 1. Pengamatan Jam 1-6

\begin{tabular}{ccccc}
\hline \multicolumn{5}{c}{ Pengamatan Jam 1 sampai Jam 6 } \\
\hline Waktu & $\mathrm{K}(+)$ & $20 \%$ & $25 \%$ & $30 \%$ \\
\hline $\mathrm{K}(+)$ & - & 0.298 & 0.130 & 0.160 \\
$20 \%$ & 0.298 & - & 0.615 & 0.020 \\
$25 \%$ & 0.130 & 0.615 & - & 0.006 \\
$30 \%$ & 0.160 & 0.020 & 0.006 & - \\
\hline
\end{tabular}

\section{KESIMPULAN}

Berdasarkan hasil penelitian ini terlihat bahwa pada semua dosis kelompok zat uji menunjukkan adanya efek antiinflamasi dimana persen inhibisi udem rata-rata setiap kelompok zat uji lebih besar dari persen udem pada kelompok kontrol negatif yang hanya diberi CMC dan dosis potensial hasil pengujian ekstrak fraksi air tepung pelepah aren yang paling besar dalam menimbulkan efek antiinflamasi pada tikus putih galur wistar (Rattus norvegicus L.) yang diinduksi karagenan yaitu dosis $30 \%$ dengan daya hambat sebesar $41.16 \%$.

\section{DAFTAR PUSTAKA}

Fitriyani, A., Winarti, L., Muslichah, S. \& Nuri. 2011. Uji Antiinflamasi Ekstrak Methanol Daun Sirih Merah (Piper Crocatum Ruiz \& Pav) pada Tikus Putih. Majalah Obat Tradisoinal, 16(1): 34-42.

Guyton, A.C., \& Hall, J.E.1997. Buku Ajar Fisiologi Kedokteran. Jakarta: EGC.

Harborne, J. B. 1987. Metode Fitokimia Penuntun Cara Modern Menganalisa Tumbuhan. Bandung: Penerbit ITB.

Hernani \& Winarti. 2011. Kandungan BahaLn Aktif Jahe dan Pemanfaatannya dalam Bidang Kesehatan. Bogor: Balai Besar Penelitian dan Pengembangan Pascapanen Pertanian.

Necas, J., \& Bartosikova, L. 2013. Carrageenan: a review, Faculty of Medicine and Dentistry. Veterinarni Medicina, 58(4): 187-205.

Nijveldt, R. J., E. van Nood, D.E.C. van Hoorn, P.G. Boelens, K. van Norren, P.A.M. van Leeuwen. 2001. Flavonoids: a review of probable mechanisms of action and potential applications. American Journal of Clinical and Nutrition, 74(4):418-425.

Prasetyo, Y.E., Sangi, M.S., \& Wuntu, A.D. 2016. Penentuan Total Fenolik dan Aktivitas Antioksidan Fraksi Etil Asetat dari Tepung Pelepah Aren (Arenga pinnata). Jurnal Ilmiah Sains, 16(2): 6972.

Robinson, T.1995. Kandungan Organik Tumbuhan Tingkat Tinggi, Bandung: Penerbit ITB.

Sangi, M.S., Momuat, L.I., \& Kumaunang, M. 2012. Uji Toksisitas Dan Skrining Fitokimia Tepung Gabah Pelepah Aren 
(Arenga pinnata). Ilmu SainS, 12 (2):127134.

Sutrisna, E. M.,Widyasari, D. F., Suprapto. 2010. Uji Efek Anti Inflamasi Ekstrak Etil Asetat Buah Semu Jambu Mete (Anacardium occidentale L.) Terhadap Udem Pada Telapak kaki Tikus Putih (Ratus Norvegiccus) Jantan Galur Wistar yang Diinduksi Karagenan. Biomedika, 2(1): 3437.

Walpole, R. E., \& Raymond, H. M. 1995. Ilmu Peluang dan Statistika untuk Insinyur dan Ilmuawan, Edisi ke-3. Jakarta: Gamedia Pustaka Utama.

Zainudin, A., U. Hasanah \& Y. R. Pemana. 2015. Uji Aktivitas Diuretik Ekstrak Akar Aren (Arenga pinnata Merr.) Terhadap Tikus Putih Galur Wistar (Rattus norvegicus) dengan Pembanding Furosemid. Jurnal Kesehatan Prim, 9(1). 1403-1411. 